Analisis Sampah Laut Dan Kelimpahan Gastropoda Di Ekosistem Mangrove Tongkaina, Sulawesi Utara

\title{
(Marine Waste Analysis And Abundance of gastropods In Mangrove Ecosystem Tongkaina, North Sulawesi)
}
M. Alaksmar Djohar ${ }^{1 *}$, Farnis B. Boneka ${ }^{2}$, Joshian N. W. Schaduw ${ }^{2}$, Stephanus V. Mandagi², Kakaskasen A. Roeroe ${ }^{2}$, Deiske A. Sumilat ${ }^{2}$

${ }^{1}$ Program Studi Magister IImu Perairan, Faklutas Perikanan dan IImu Kelautan, Universitas Sam Ratulangi, Jl. Kampus Unsrat Bahu, Manado 95115 Sulawesi Utara, Indonesia

${ }^{2}$ Staf Pengajar pada Fakultas Perikanan dan IImu Kelautan, Universitas Sam Ratulangi, JI. Kampus Unsrat Bahu, Manado 95115, Sulawesi Utara, Indonesia

${ }^{\star}$ Corresponding Authors: alaksmardj19@yahoo.com

\begin{abstract}
This study aims to analyze the relation of marine debris to gastropods in the mangrove ecosystem. This research was conducted from October to December 2019 in the Tongkaina mangrove forest. The method used in this research is the line transects method with 2 different stations. Then do the data analysis of waste density, gastropod abundance index, frequency, diversity index, uniformity and dominance. Then, alyzing a simple linear regression and correlation are performed to see the relationship between marine debris and gastropod abundance in mangrove ecosystem. The results showed that the highest inorganic marine debris in the Tongkeina mangrove ecosystem is plastic and followed by cloth, wood, metal and the least was glass. The species of Gastropods found in the mangrove ecosystem are Littoraria scabra, Nerita undulata and Terebralia sulcata. The highest abundance of gastropod species was found at station 2 in transects 1 by Littoraria scraba. The results of the linear regression analysis show that there is a relationship between waste and abundance of gastropods. The increasing amount of waste, lower the abundance of gastropods. Where the correlation value is -0.20506 .
\end{abstract}

Keywords: Correlation; Marine debsris; Gastropods; Mangrove Ecosystem.

\section{ABSTRAK}

Penelitian ini bertujuan untuk menganalisis hubungan sampah laut terhadap gastropoda di ekosistem mangrove. Penelitian ini dilakukan pada bulan Oktober sampai Desember 2019 di hutan mangrove Tongkaina. Metode yang digunakan adalah metode line transek dengan 2 stasiun berbeda. Kemudian dilakukan analisa data kepadatan sampah, indeks kelimpaha gastropoda, frekuensi, indeks keanekaragaman, keseragaman dan dominasi. Selanjutnya dilakukan analisa regresi lineier sederhana serta korelasi untuk melihat hubungan yang terjadi antara sampah dan kelimpahan gastrooda. Hasil penelitian menunjukkan bahwa sampah anorganik jenis plasik yang tertinggi di ekosistem mangrove pantai Tongkaina diikuti sampah jenis Kain, Kayu, Logam dan yang paling sedikit adalah sampah jenis kaca. Jenis gastropoda yang ditemukan di ekosistem mangrove yaitu Littoraria scabra, Nerita undulata dan Terebralia sulcata. Nilai kelimpahan jenis gastropoda tertinggi terdapat di stasiun 2 di transek 1 oleh Littoraria scraba. Hasil analisa regresi linier menunjukan bahawa ada hubungan yang terjadi antara sampah dan kelimpahan gastropoda yang dilihat dari anlisis regresi linier sederhana. Semakin meningkatnya jumlah sampah maka semakin rendah kelimpahan gastropoda. Dimana nilai korelasinya sebesar -0.20506 .

Kata Kunci : Korelasi; Sampah Laut; Gastropoda; Ekosistem Mangrove.

\section{Pendahuluan}

Desa Tongkaina terletak di Kecamatan Bunaken, Provinsi Sulawesi Utara. Desa Tongkaina dengan luas 858 hektar memiliki jumlah penduduk 1.866 jiwa. Masyarakat desa setempat berprofesi lebih dominan sebagai Nelayan. Desa Tongkaina memiliki hutan mangrove yang 
lokasinya terdapat tidak terlalu jauh dari pemukiman warga dan sangat mudah untuk diakses oleh publik. Sering meningkatnya penduduk semakin meningkat pula pencemaran sampah yang dihasilkan.Pencemaran adalah suatu keadaan dimana terjadi penambahan bermacam-macam bahan dari aktivitas manusia ke dalam lingkungannya yang memberikan pengaruh berbahaya dan dapat merubah sifat asli dari lingkungan tersebut baik fisik, kimia dan biologi. Laut menjadi tempat pembuangan akhir dari sampah yang berasal dari industry dan aktivitas manusia. Sampah laut yang sering dijumpai yaitu, plastik, kain, busa, Styrofoam, kaca, keramik, logam, kertas, karet dan kayu. Plastik merupakan tipe sampah laut dominan (CBDSTAP, 2012). Plastik merupakan polimer organik sintetis dan memiliki karakteristik bahan yang cocok digunakan dalam kehidupan seharihari (Derraik, 2002). Tetapi karena sifatnya yang sulit untuk terurai dan sifat tambahan lainnya yang telah terbukti memiliki efek toksik pada makhluk hidup menyebabkan sampah plastik perlu dikelola dengan baik. Sampah yang dibuang di laut akan terbawa arus dan masuk ke perairan dalam ataupun kembali ke pesisir pantai. Sampah yang masuk ke dalam ekosistem mangrove akan memberikan dampak kepada biota yang berasosiasi didalamnya (Hartoni dan Agusalim, 2013)

Indonesia dilaporkan memiliki hutan mangrove sebesar 4.25 juta ha (sekitar $27 \%$ dari luas hutan mangrove di dunia) (Saptarini dkk., 2011). Hutan mangrove merupakan kawasan terluas di dunia yang memiliki keanekaragaman yang sangat tinggi dan strukturnya yang bervariasi. Ekosistem mangrove menjadi begitu penting karena banyak hewan dan tumbuhan yang menghabiskan sebagian hidupnya untuk tinggal di ekosistem ini (Schaduw, 2015). Salah satu biota yang sering dijumpai di ekosistem mangrove adalah moluska. Moluska yang paling banyak ditemui di hutan mangrove yaitu gastropoda (Saptrini dkk., 2011). Isnaningsih dan Patria (2018) menjelaskan bahwa gastropoda memiliki peran penting dalam ekosistem mangrove yang mendukung fungsi-fungsi ekologis dari mangrove. Gastropoda membantu dalam proses rantai makanan dan siklus nutrient yang melibatkan mangrove dimana, gastropoda dapat menjadi konsumen pertama maupun sebagai pengurai. Cangkang yang terdapat pada gastropoda tersusun dari bahan kalsium karbonat yang turut berperan untuk siklus karbon yang terjadi di hutan mangrove walaupun perlu dikaji lebih lanjut.

Gastropoda mempunyai peranan yang sangat penting baik dari segi ekologi dan ekonomi. Dari segi ekologi gastropoda berperan sebagai konsumen sedangkan dari segi ekonomi gastropoda memiliki harga jual yang tinggi. Sifat dari gastropoda yang selalu menetap menyebabkan spesies ini menerima setiap perubahan yang terjadi di hutan mangrove yang secara tidak langsung mempengaruhi kelimpahan gastropoda. (Hartoni dan Agusalim, 2013).

\section{Metodologi Penelitian}

Penelitian ini mengambil data dan sampel di daerah Mangrove Tongkaina, kota Manado Sulawesi Utara (gambar 1). Sampah yang terdapat di lokasi mangrove di ambil kemudian di bersihkan, dikeringkan, dihitung, ditimbang identifikasi dan dilanjutkan dengan analisa data untuk mendapatkan nilai kepadatannya. Penelitian ini juga menganalisis struktur komunitas dan kelimpahan gastropoda yang ada di ekosistem mangrove Tongkaina. Sampel gastropoda yang ditemukan dihitung kelimpahan, diidentifikasi jenis apa yang ditemukan dan dilanjutkan dengan analisa data. Waktu pelaksanaan penelitian dilakukan dari Oktober sampai Desember 2019. Metode yang digunakan dalam penelitian ini yaitu metode survey dimana Untuk pengambilan sampel seperti sampah dan gastropoda digunakan metode transek plot garis/line plot sampling (Noor et al., 1999; Febriansyah, 2018). Stasiun penelitian di pusatkan di dalam ekosistem mangrove. Stasiun di tetapkan sebanyak 2 dimana lokasi stasiun 1 adalah yang berdekatan dengan pemukiman warga dan stasiun 2 
yang jauh dari pemukiman, dengan panjang area garis transek mulai dari batas daratan tumbuhnya mangrove sampai batas laut dimana mangrove masih bisa tumbuh.

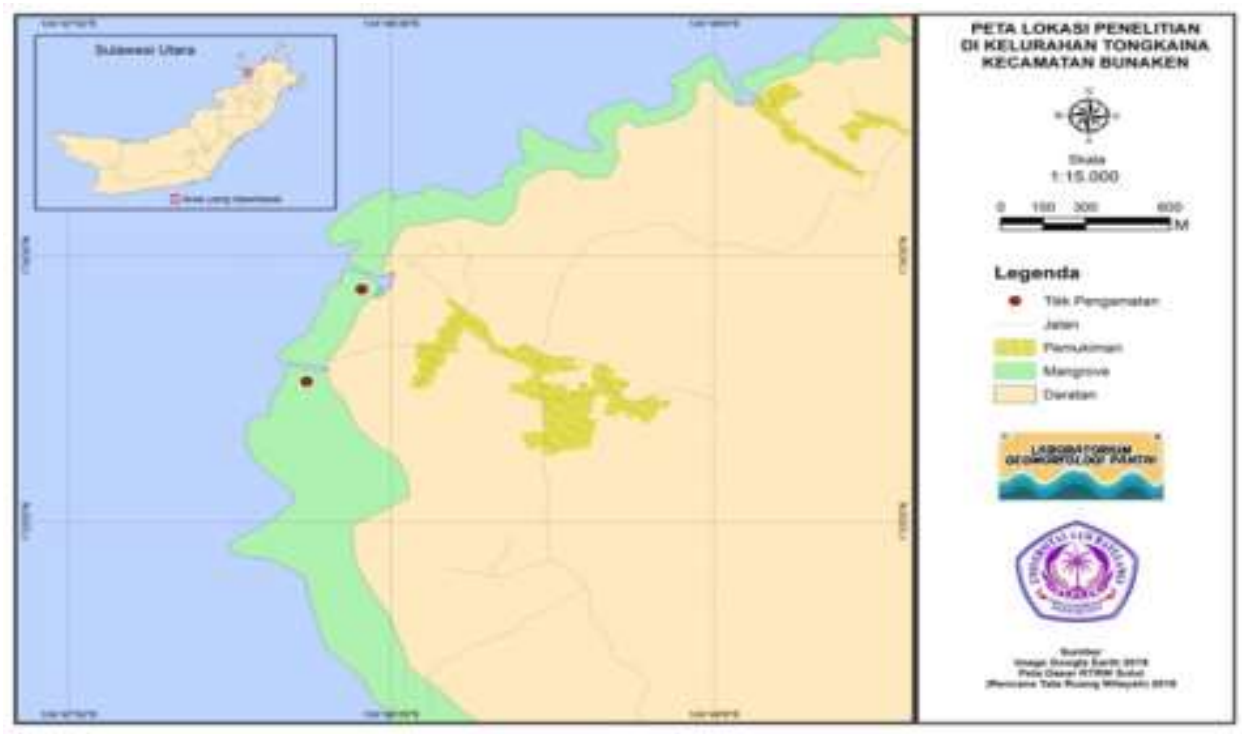

Gambar 1. Peta Lokasi penelitian

\section{Analisis Data}

Setelah sampel yang berupa sampah laut dikumpulkan, maka dilanjutkan dengan pengelompokkan sampah ke dalam gologan seperti plastic dan karet, logam, kaca serta kayu dan turunannya. Masingmasing jenis dihitung jumlah dan beratnya pada tiap-tiap transek. Selanjutnya dilakukan Perhitungan total jenis dan berat sampah mengikuti persamaan berikut ini (Coe dan Rogers, 1997; Walalangi, 2012).

1. Kepadatan mutlak (Jumlah potongan sampah) $=$ Jumlah potongan sampah dalam tiap kategori Luas Area $\left(\mathrm{m}^{2}\right)$

2. Kepadatan mutlak (berat sampah)

Bearat potongan sampah laut dalam tiap kategori

$$
\text { Luas Area }\left(\mathrm{m}^{2}\right)
$$

3. Kepadatan relatif (Jumlah potongan sampah) $=$

$$
\frac{\text { Jumlah potongan sampah dalam tiap kategori }}{\text { Jumlah total berat potongan sampah dalam semua kategori }} \times 100 \%
$$

4. Kepadatan relatif (berat sampah) $=$

$$
\text { Berat potongan sampah dalam tiap kategori } \quad \times 100 \%
$$

Tiap individu yang di dapat kemudian di foto dan di identifikasi. Suatu spesies dikatakan melimpah apabila ditemukan dalam jumlah yangsangat banyak dibandingkan dengan individu dari spesies lain. Oleh karena itu dilakukan analisa kelimpahan gastropoda meliputi :
- Kelimpahan

$$
\mathrm{N}=\frac{\mathrm{ni}}{\mathrm{A}}
$$

Keterangan :

$\mathrm{N}$ = Kelimpahan

$\mathrm{ni}=$ Jumlah individu spesies gastropoda

$A=$ Luas total $\left(\mathrm{m}^{2}\right)$ 
- Frekuensi

$$
F_{i}=\frac{p_{t}}{\sum_{t=1}^{n} p_{t}}
$$

Keterangan :

$\mathrm{Fi}=$ Frekuensi spesies ke $\mathrm{i}$

$\mathrm{ni}=$ Jumlah petak contoh dimana ditemukan spesies ke i

- Frekuensi Relatif

Keterangan :

$$
R F_{1}-\left(\frac{F_{1}}{\sum_{i=1}^{n} F_{i}}\right) \times 100
$$

$\mathrm{RFi}=$ Frekuensi relatif spesies ke $\mathrm{i}$

$\mathrm{Fi}=$ Frekuensi spesies ke $\mathrm{i}$

- Indeks Keanekaragaman

$$
H^{\prime}=-\sum_{i=1}^{5} P i \ln P i
$$

Keterangan :

$H^{\prime}=$ Indeks Keanekaragaman

ni = Jumlah individu spesies ke-i

$\mathrm{N}=$ Jumlah total individu

$\mathrm{Pi}=$ Proporsi individu spesies ke $\mathrm{i}$

$\mathrm{i}=1,2,3 \ldots \ldots \ldots, \mathrm{s}$

$\mathrm{S}=$ Jumlah genera

- Indeks Keseragaman

$$
I^{\prime}=\frac{H^{\prime}}{\ln (S)}
$$

Keterangan :

$\mathrm{J}^{\prime}:$ Indeks Keseragaman Spesies

$H^{\prime}$ : Indeks keanekaragaman Shannon-Wiever

$S$ : Jumlah spesies

- Indeks Dominasi

$$
\mathrm{D}=\sum(n i / N)^{3}
$$

$$
\begin{aligned}
& \text { Keterangan: } \\
& \mathrm{D} \quad=\text { Indeks dominasi } \\
& \mathrm{Ni} \quad \text { = Jumlah individu spesies ke-i } \\
& \mathrm{N} \quad \text { = Jumlah total individu }
\end{aligned}
$$

Selanjutnya keseluruhan hasil yang di dapat akan dilakukan analisa stastistika yaitu regresi. Analisa ini memanfaatkan hubungan antara dua atau lebih kuantitatif sehingga salah satu peubah dapat diramal dari peubah lainnya (Kismiantini, 2010). Kofesien korelasi merupakan pengukuran statistic kovarian atau asosisasi antara 2 variabel. Dimana besarnya koefesien korelasi berkisar antara $+1 \mathrm{~s} / \mathrm{d}-1$. Koefisien korelasi menunjukan kekuatan (straight) hubungan linier dan arah hubungan dua variable acak. Jika koefisien korelasi positif maka kedua variable mempunyai hubungan searah, artinya jika nilai $X$ tinggi, maka nilai variable $Y$ akan tinggi. Sebaliknya, jika nilai koefesien negatif maka artinya jika nilai $X$ tinggi maka nilai variable $Y$ akan menjadi rendah dan berlaku sebaliknya (Salim, 2019; Sarwono, 2006).

\section{Hasil Dan Pembahasan}

\section{Hasil Analisa Sampah Anorganik}

Kawasan ekosistem Mangrove yang berada di Tongkaina menjadi kawasan mangrove yang paling mudah dijangkau. Letak lokasi yang tidak terlalu jau dari pemukiman warga menjadikan area ini dipenuhi banyak aktivitas. Salah satu aktivitas yang sering dijumpai adalah aktivitas melaut dimana area mangrove Tongkaina menjadi tempat bagi nelayan yang ingin memancing dan menjalankan bisnis transportasi laut untuk mengangkut penumpang dari Tongkaina ke bunaken ataupun sebaliknya menggunakan perahu. Aktivitas tersebut ternyata memberikan dampak yang cukup signifikan bagi kebersihan lingkungan di kawasan pantai mangrove karena tidak dikelola dengan baik. Beberapa aktivitas seperti perhotelan yang berada tidak jauh dari area mangrove dan aktivitas masyarakat pesisir juga memberikan kontribusi masuknya sampah anorganik ke ekosistem mangrove.

Berdasarkan pengamatan yang dilakukan maka diperolah sampah laut yang dijumpai di daerah penelitian, dimana terdapat 4 kategori jenis sampah laut yaitu sampah plastic, logam, kaca dan kayu (gambar 2).

Data yang telah diperoleh menunjukan bahwa adanya perbedaan dalam total keseluruhan potongan sampah di staisun 1 dan 2. Stasiun 1 memiliki jumlah keseluruhan total potongan sampah sebesar 82 pot $/ 1100 \mathrm{~m}^{2} \quad(745.45 \mathrm{Pot} / \mathrm{Ha})$ dengan berat $4075 \mathrm{gram} / 1100 \mathrm{~m}^{2}(37.045,4$ gram $/ \mathrm{Ha})$, dimana jumlah potongan sampah anorganik terbanyak di stasiun 1 jenis plastik, yaitu dengan total potongan sebanyak 68 pot/1100m² $(618.18 \mathrm{Plot} / \mathrm{Ha})$ dengan berat 2833 gram $/ 1100 \mathrm{~m}^{2}$ (25.454.54 gram/Ha) diikuti dengan 
sampah jenis kain sebanyak 12 pot/1100 m2 (109.09 $\mathrm{Plot} / \mathrm{Ha})$ dengan berat 556 gram/1100m2 (5,054.54 gram/Ha) dan dilanjutkan dengan kayu sebanyak 3 $\mathrm{Plot} / \mathrm{m}^{2}$ (27.27 Plot/Ha) dengan berat total $686 \mathrm{gram} / 1100 \mathrm{~m}^{2}$ (6.236.36 gram/Ha). Untuk kategori logam, karet dan kaca tidak ditemukan di lokasi stasiun 1.Selanjutnya jumlah total sampah anorganik yang di dapati di stasiun 2 yaitu sebanyak 194 Plot/1200m² (1.616 Plot/Ha) dengan berat $7648 \mathrm{gram} / 1200 \mathrm{~m}^{2}$ (63.733.3 $\left.\mathrm{gram} / \mathrm{Ha}\right)$, dimana sampah plastik masih menjadi sampah yang paling banyak jumlahnya dengan potongan sampah sebanyak 184
Plot/1200m² (1.533 Plot/Ha) dengan berat sampah plastik sebesar $6348 \mathrm{gram} / 1200 \mathrm{~m}^{2}$ (52.900 gram/Ha) diikuti sampah jenis kain sebanyak $5 \mathrm{Plot} / 1200 \mathrm{~m}^{2}$ (41.666 Plot/Ha) dengan berat 680 gram $/ 1200 \mathrm{~m}^{2}(5.666 .6$ gram $/ \mathrm{Ha}$ ). Jenis sampah lain yang ditemukan yaitu logam dimana jumlah potongan sebesar 3 Plot $/ 1200 \mathrm{~m}^{2} \quad(25$ $\mathrm{Plot} / \mathrm{Ha})$ dengan berat sebesar 130 gram $/ 1200 \mathrm{~m} 2$ (1.083.3 gram/Ha) dan diikuti dengan sampah jenis kaca sebanyak 2 Pot $/ 1200 \mathrm{~m}^{2}$ (16.66 Plot/Ha) dengan berat sampah sebesar 490 gram $/ 1200 \mathrm{~m}^{2}$ (4.083.3 gram/Ha). Sampah jenis kayu tidak ditemukan di stasiun 2 .

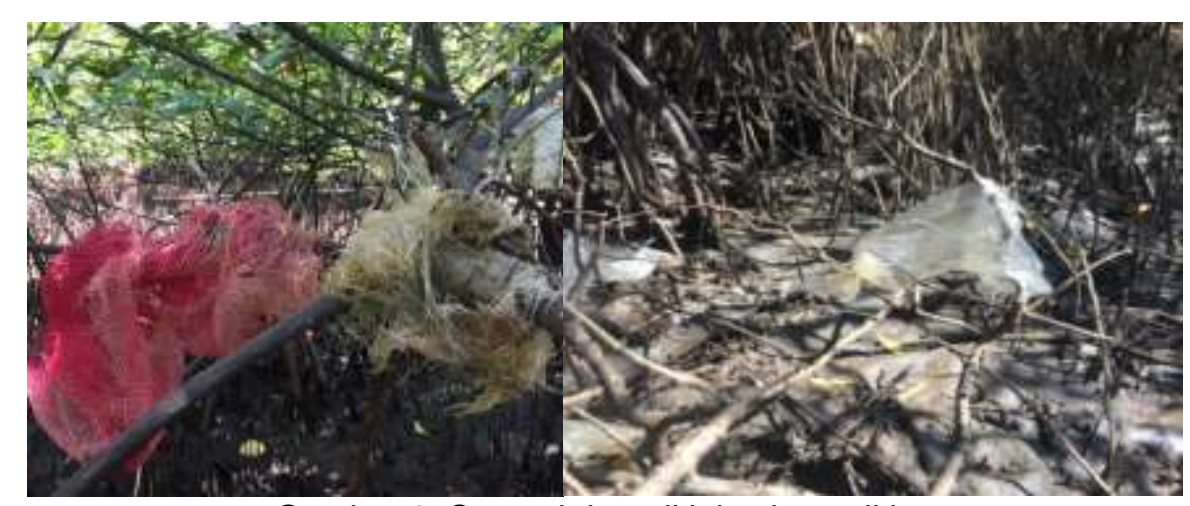

Gambar 2. Sampah laut di lokasi penelitian

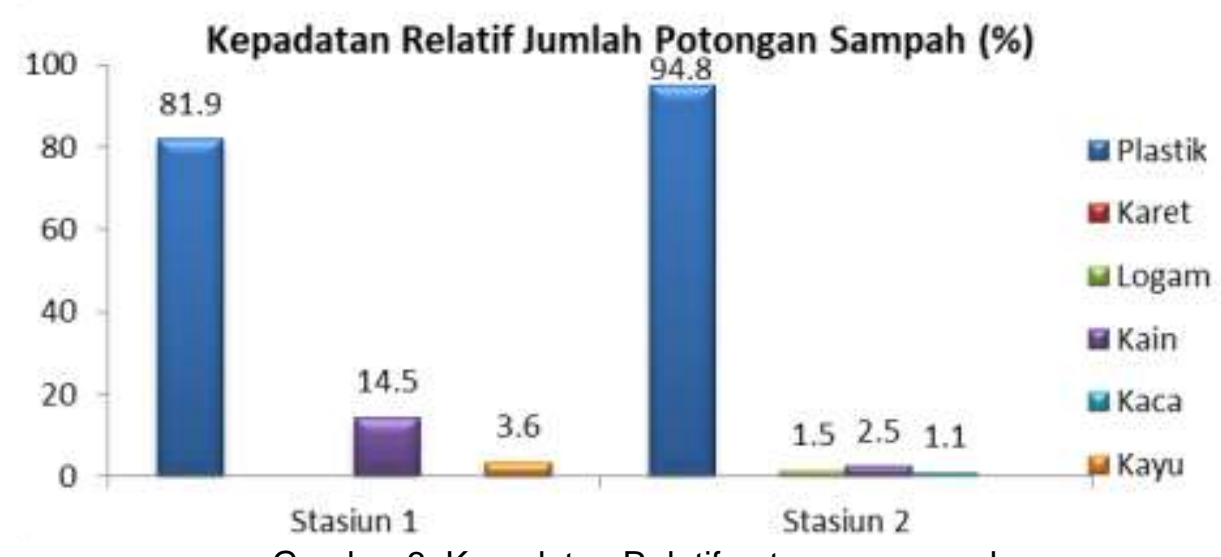

Gambar 3. Kepadatan Relatif potongan sampah

Persentase kepadatan sampah anorganik di ekosistem mangrove pantai Tongkaina diurutkan berdasarkan peringkat dimana sampah jenis plasik yang menjadi yang tertinggi yaitu sebesar $91 \%$, diikuti sampah jenis Kain 6,1\%, Kayu 1.5\%, Logam 1.1.\% dan yang paling sedikit adalah sampah jenis kaca $(0.7 \%)$ dan untuk sampah jenis karet tidak ditemukan di ekosistem mangrove tongkania. Hal serupa juga ditemukan dalam penelitian Djaguna, (2019) dimana sampah jenis plastik menjadi sampah terbanyak yang di temukan di pesisir pantai Tongkaina. Sebagian sampah yang ditemukan diduga berasal dari ativitas masyarakat yang tinggal berdekatan dengan pesisir dan sebagiannya terbawa oleh arus. Penyebaran sampah laut di wilayah pesisir sangat dipengaruhi oleh pergerakan arus 
dan angin. Gerakan massa air / arus tersebut dapat membawa sampah di perairan dengan jarak yang cukup jauh (NOAA, 2015). Menurut Kaladharan et al,
(2004) menjelaskan bahwa jumlah debris di pantai berkorelasi signifikan dengan kecepatan angin, namun tidak berkorelasi dengan arah angin.

\begin{tabular}{ccc}
\multicolumn{3}{c}{ Tabel 1. Presentase kepadatan total sampah } \\
\hline Peringkat & Jenis sampah & Potongan \\
\hline 1 & Plastik & $91 \%$ \\
2 & Kain & $6.1 \%$ \\
3 & Kayu & $1.5 \%$ \\
4 & Logam & $1.1 \%$ \\
5 & Kaca & $0.7 \%$ \\
6 & Karet & $0 \%$ \\
\hline & Total & $100 \%$ \\
\hline
\end{tabular}

\section{Hasil Analisa Kelimpahan Gastropoda}

Dilihat dari kedua stasiun ditemukan 3 spesies gastropos yaitu jenis Littoraria scabra, Nerita undulata dan Terebralia sulcata. Ketiga spesies ini ditemukan di tiap transek dengan jumlah kelimpahan individu yang berbeda-beda (gamabar 4). Littoraria scabra ditemukan di batang dan daun, Terebralia sulcata ditemukan di akar dan batang, sedangkan Nerita undulata ditemukan di akar mangrove.Nilai kelimpahan jenis tertinggi pada stasiun $1 \mathrm{di}$ transek 1 yaitu dimiliki oleh Terebralia sulcata yaitu $1.0 \mathrm{ind} / \mathrm{m}^{2}$ dan kelimpahan terendah dimiliki oleh Nerita undulata yaitu $0.01 \mathrm{ind} / \mathrm{m}^{2}$, dengan nilai kelimpahan relatif sebesar $68.93 \%$ dan $2.92 \%$. Pada transek 2 nilai tertinggi dimiliki oleh Terebralia sulcata $0.24 \mathrm{ind} / \mathrm{m}^{2}$ dan yang terendah dimiliki oleh Nerita undulata $0.03 \mathrm{ind} / \mathrm{m}^{2}$, dimana nilai kerlimpahan relatifnya sebesar $73.48 \%$ dan $8.33 \%$. Pada transek 3 nilai tertinggi diperoleh oleh spesies Terebralia sulcata dengan nilai kelimpahan sebesar $0.14 \mathrm{ind} / \mathrm{m} 2$ sedangan nilai terendah dimiliki oleh spesies Nerita undulata yaitu nilai kelimpahannya sebesar $0.02 \mathrm{ind} / \mathrm{m}^{2}$, dimana nilai kelimpahan relatifnya sebesar $63.33 \%$ dan $8.89 \%$. Pada stasiun 2 transek 1, nilai tertinggi dimiliki oleh Littoraria scabra yaitu, 0.26 ind $/ \mathrm{m} 2$ dan yang terendah dimiliki oleh Terebralia sulcata yaitu $0.07 \mathrm{ind} / \mathrm{m} 2$, dengan nilai kelimpahan relaif yaitu $78.79 \%$ dan $21.21 \%$. Pada transek 2 nilai tertinggi dimiliki oleh Littoraria scabra yaitu, $0.19 \mathrm{ind} / \mathrm{m} 2$ dan yang terendah dimiliki oleh Nerita undulata yaitu $0.01 \mathrm{ind} / \mathrm{m} 2$, dengan nilai kelimpahan relatifnya yaitu $64.91 \%$ dan $32.46 \%$. Pada transek 3 nilai tertinggi dimiliki oleh Littoraria scabra yaitu, $0.17 \mathrm{ind} / \mathrm{m} 2$ dan yang terendah dimiliki oleh Nerita undulata yaitu $0.02 \mathrm{ind} / \mathrm{m} 2$, dengan nilai kelimpahan relatifnya yaitu, $62.73 \%$ dan $30 \%$. Kelimpahan Littoraria scabra dipengaruhi juga dengan pola zonasi dimana menurut Lalita dan Rangan (2018), habitat L. scraba paling banyak ditemukan pada zonasi mangrove depan yang berhadapan dengan laut.

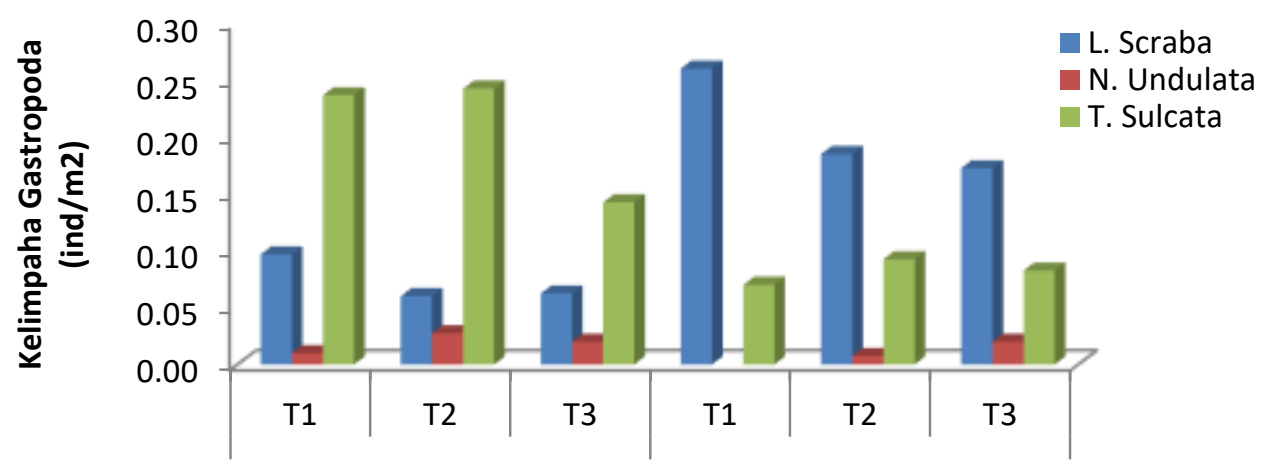

Gambar 4. Kelimpahan relatif gastropoda 


\section{Indeks Frekuensi}

Nilai frekuensi jenis tertinggi pada stasiun 1 transek 1, dimiliki oleh Littoraria scabra, Nerita undulate dan Terebralia sulcata yaitu $1.00 \mathrm{ind} / \mathrm{m}^{2}$, dengan nilai frekuensi relatif sebesar $33.33 \%$ dan $11.11 \%$. Pada transek 2 nilai tertinggi dimiliki Littoraria scabra dan Terebralia sulcata yaitu $1.00 \mathrm{ind} / \mathrm{m}^{2}$ dan nilai terendah dimiliki oleh Nerita undulate yaitu 0.75 ind $/ \mathrm{m} 2$, dimana nilai frekuensi relatifnya sebesar $33.33 \%$ dan $27.27 \%$. Pada transek 3 nilai tertinggi diperoleh oleh spesies Littoraria scabra, Nerita undulate dan Terebralia sulcata yaitu $1.00 \mathrm{ind} / \mathrm{m}^{2}$ sedangkan nilai frekuensinya sebesar 0.75 ind $/ \mathrm{m}^{2}$, dimana nilai frekuensi relatifnya yaitu $33.33 \%$. Pada stasiun 2 transek 1 , nilai tertinggi dimiliki oleh Littoraria scabra yaitu, $1.00 \mathrm{ind} / \mathrm{m} 2$ dan yang terendah dimiliki oleh Terebralia sulcata yaitu 0.75 ind $/ \mathrm{m} 2$, dengan nilai frekuensi relaif yaitu $66.67 \%$ dan $33.33 \%$. Pada transek 2 nilai tertinggi dimiliki oleh Littoraria scabra 1.00 $\mathrm{ind} / \mathrm{m}^{2}$ dan yang terendah dimiliki oleh Nerita undulate yaitu, $0.25 \mathrm{ind} / \mathrm{m}^{2}$ dengan nilai frekuensi relatifnya yaitu, $50 \%$ dan $12.50 \%$. Pada transek 3 nilai tertinggi dimiliki oleh Littoraria scabra yaitu, 1.00 ind $/ \mathrm{m}^{2}$ dan nilai terendah dimiliki oleh spesies Nerita undulate dengan nilai frekuensi relatifnya yaitu, $50 \%$ dan $20 \%$. Boneka, (2001) menjelaskan bahwa Speises Littoraria scabra secara eksklusif menempati kulit bakau dan akar dimana mereka bergerak naik dan turun mengikuti permukaan air untuk menghindari terendam air laut.

\section{Hasil Indeks Keanekaragaman, keseragaman dan Dominasi}

Indeks keanekaragaman tertinggi di stasiun 1 yaitu terdapat pada transek 3 dengan nilai $0.86 \%$ dan yang terendah yaitu di transek 1 dengan nilai $0.72 \%$. Pada stasiun 2 indeks keanekaragaman tertinggi terdapat di transek 3 dengan nilai $0.84 \%$ dan keanekaragaman terendah ditemukan di transek 1 yaitu 0.75 . Dari kedua stasiun dapat dilihat bahwa nilai keanekaragaman tertinggi terdapat di stasiun 1 . Nilai keseragaman yang tertinggi di stasiun 1 dijumpai di transek 3 yaitu $0.78 \%$ dan yang terendah di transek 1 yaitu $0.65 \%$, sedangkan pada stasiun 2 nilai tertinggi untuk keseragaman dijumpai di transek 1 yaitu $0.78 \%$ dan nilai terendah ditemukan di stasiun 2 yaitu $0.65 \%$. Dari kedua stasiun dapat dilihat bahwa nilai keseragaman tertinggi terdapat di stasiun 3. Nilai dominansi yang tertinggi di stasiun 1 terdapat di transek 2 yaitu $0.58 \%$ dan yang terendah $0.49 \%$. Pada stasiun 2 nilai dominasi tertinggi terdapat di transek 1 yaitu $0.67 \%$ dan yang terendah ditemui di transek 3 yaitu $0.49 \%$. Dari kedua stasiun dapat dilihat bahwa nilai dominasi tertinggi terdapat di stasiun 2 .

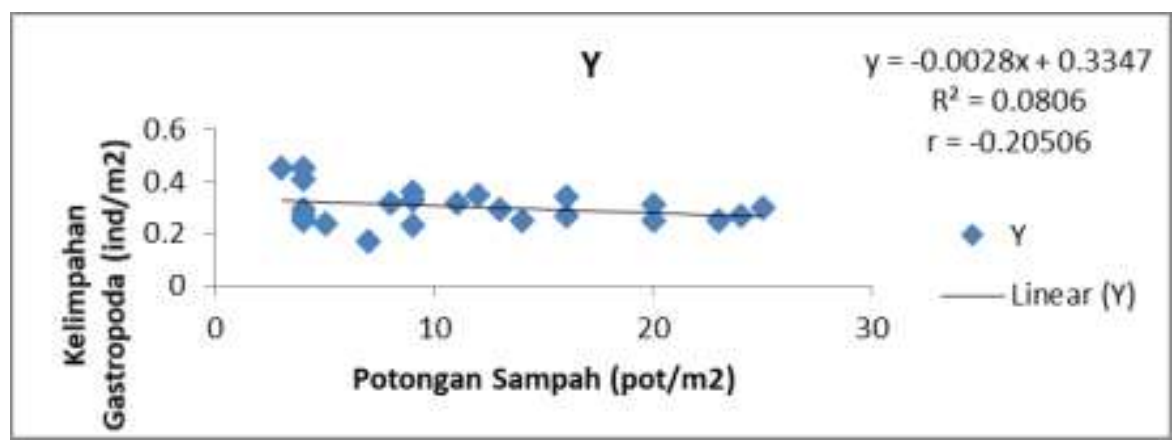

Gambar 5. Hasil analisa regresi dan korelasi

\section{Hasil Analisa uji regresi dan korelasi sampah dan gastropoda}

Hasil analisa uji regresi yang didapat dari penelitian ini menunjukan bahwa ada hubungan yang terjadi antara potongan sampah dan kelimpahan gastopoda.
Dimana hasil analisa regresi menunjukan nilai $R^{2}$ yaitu 0.0806 yang artinya ada hubungan yang terjadi diantara keduanya (Gambar 5). Sedangkan analisa korlasi yang dilakukan menunjukkan bahwa nilai $r$ yaitu -0.20506 , dimana dalam korelasi jika 
hasil $r$ didapati positif maka kedua variable mempunyai hubungan searah, artinya jika variable $X$ tinggi maka nilai $Y$ akan tinggi pula dan begitupun sebaliknya, jika hasilnya mines artinya jika nilai $X$ tinggi maka nilai $Y$ akan menurun (Sarwono, 2006; Salim dkk., 2019). Oleh karena itu dari hasil tersebut menunjukan bahwa setiap kenaikan jumlah potongan sampah maka kelimpahan gastropoda menurun. Hal ini diperkuat oleh pernyataan Hartoni dan Agusalim (2013) yang menyatakan bawa sifat dari gastropoda yang selalu menetap menyebabkan spesies ini menerima setiap perubahan yang terjadi di hutan mangrove yang secara tidak langsung mempengaruhi kelimpahan gastropoda.

\section{Kesimpulan}

\section{Kesimpulan Dan Saran}

Sampah laut anorganik yang teridentifikiasi di lokasi penelitian adalah sampah jenis plastik, kain, karet, logam, kaca, serta kayu dan turunan. Dari dua stasiun jumlah sampah terbanyak ditemukan di stasiun 2. Sampah plastik merupakan sampah yang paling banyak di temukan pada lokasi, diikuti dengan jenis kain, kaca, kayu dan logam untuk jenis karet tidak ditemukan.Jenis gastropoda yang ditemukan di eksistem mangrove yaitu Littoraria scabra, Nerita undulata dan Terebralia sulcata. Nilai kelimpahan jenis gastropoda tertinggi terdapat di stasiun 2 di transek 1 oleh Littoraria scraba sedangkan nilai terendah ditemui di stasiun 1 transek 1 dan stasiun 2 transek 2 oleh jenis Nerita undulate. Dari penelitian ini ditemukan bahawa ada hubungan yang terjadi antara sampah dan kelimpahan gastropoda yang dilihat dari anlisis regresi linier sederhana. Semakin meningkatnya jumlah sampah maka semakin rendah kelimpahan gastropoda. Dimana nilai korelasinya sebesar . 0.20506 .

\section{Saran}

Perlu adanya penelitian lanjut untuk sampah laut dan gastropoda sehingga dapat menjadi data pembanding terhadap perkembangan ataupun perubahan yang terjadi.

\section{Ucapan Terima Kasih}

Penulis mengucapkan terima kasih kepada Kementerian Pendidikan dan Kebudayaan Rebulik Indonesia melalui hibah kompetitif skim riset terapan dengan ketua peneliti Dr. Joshian Nicolas William Schaduw, S.IK, M.Si yg telah membantu dalam kajian ini, beserta semua pihak yg ambil bagian dalam kajian ini hingga penelitian ini dapat dilaksanakan.

\section{Daftar Pustaka}

Boneka, F, B. 2001. Feeding Period of Littoraria scraba (Littorinidae: Prosobranchia) on Bunaken Island, Indonesia. Phuket Marine Bilogical Center Special Publication. Vol 25(1):252-253.

Convention on Biologica Diversity Scientific and Technical Advisory Panel (CBD). 2012. Impacts of Marine Debris on Biodiversity: Current Status and Potential Solutions. CBD Technical Series No. 67. Secretariat of the Convention on Biological Diversity.Montreal (CA).

Derraik, J, G, B. 2002. The pollution of the marine environment by plastic debris: a review. Marine Pollution Bulletin. 44: 842-852.

Djaguna A., Pelle, W, E., Schaduw, J, N, W., Manengkey, H, W, K., Rumampuk, N, D, C., Ngangi, E, L, A. 2019. Identifikasi Sampah Laut di Pantai Tongkaina dan Talawaan Bajo. Jurnal Pesisir dan Laut Tropis. Volume 7 Nomor 3

Febriansyah., D, Hartono., B, F, Negara., P, P, Renta., Y, P, Renta. 2018 Struktur Komunitas Hutan Mangrove di Pulau BAAl Kota Bengkulu. EISSN: 2527-5186. P-ISSN: 26155958. Jurnal Enggano. Vol 3, No 1: 112-128.

Hartoni \& A, Agussalim. 2013. Komposisi dan Kelimpahan Moluska (Gastropoda dan Bivalvia) di Ekosistem Mangrove Muara Sungai Musi Kabupaten Banyuasin Provinsi 
Sumatra Selatan. Maspari Journal. Volume 5, Nomor 1: 6-15. Universitas Sriwijawa.

Isnaningsih, N, R., \& M, P, Patria. 2018. Peran Komunitas Moluska dalam Mendukung Fungsi Kawasan Mangrove di Tanjung Lesung, Pandeglang, Banten. Jurnal Biotropika. Volume 6 No.2. Universitas Indonesia

Kaladharan P, Prema D, Nandakumar A, Valsala KK. 2004. Occurrence of tarball and Waste Materials on the beaches along Kerala coast in India. J M ar Biol Assoc India. 46 (1): 93-97.

Kismiantini. 2010. Handout Analisis Regresi. PPT. Universitas Negeri Yogyakarta

Lalita, J, D., \& R, Jety, K. 2018. Signifikasi Adaptif Ekologi Litoraria scraba (Gastropdoda LITTORIDAE), Untuk Survival di Lingkungan Mangrove Tombariri yang Ekstrim. Vol 6(2), 2302-3589

National Oceanic and Atmospheric Administration (NOAA). 2015. Turning The Tide On Trash. A Learning Guide On Marine Debris. NOAA PIFSC CRED.

Salim, G., R, Dori., A. Rahma. 2019. Hubungan Kerapatan mangrove dengan Kelimpahan Gastropoda di Kawasan Konservasi Mangrove dan Bekantan (KKMB) Kota Tarakan. Jurnal Harpodon Borneo. Volume 12 (2): 2087-121X.
Saptarini, D., I, Trisnawati., M, A, Hadiputra. 2011. Struktur Komunitas Gastropoda (Moluska) Hutan Mangrove Sendang Biru, Malang Selatan. Surabaya, Indonesia

Schaduw, J, N, W. 2015. Bioekologi Mangrove Daerah Perlindungan Laut Berbasis Masyarakat Desa Blongko Kecamatan Sinonsayang Kabupaten Minahasa Selatan Provinsi Sulawesi Utara. Jurnal LPPM Bidang Sains dan Teknologi. Volume 2, Nomor 1: 89102.

Schaduw, J, N, W. 2015. Keberlanjutan Pengelolaan Ekosistem Mangrove Pulau Mantehage, Kecamatan Wori, Kabupaten Minahasa Utara Provinsi Sulawesi Utara. Jurnal LPPM Bidang Sains dan Teknologi. Volume 2, Nomor 2: 60-70.

Schaduw, J, N, W. 2016. Evaluasi Pengelolaan Ekosistem Mangrove Pada Daerah Perlindungan Laut di Desa Blongko, Kecamatan Sinosayang Kabupaten Minahasa Selatan Provinsi Sulawesi Utara. SAPTIAL Wahana Komunikasi dan Informasi Geografi. Volume 6, Nomor 2: 27-38.

Walalangi, J. Y. 2012. Analisis Komposisi Sampah Organik dan Anorganik Serta Dampak Terhadap Lingkungan Pesisir Kota Palu Sulawesi Utara. Jurnal Biologi. Institut Pertanian Bogor. 